\title{
AC 2010-118: SUPPORTS AND BARRIERS THAT RECENT ENGINEERING GRADUATES EXPERIENCE IN THE WORKPLACE
}

\section{Samantha Brunhaver, Stanford University}

Samantha Brunhaver is a second year graduate student at Stanford University. She is currently working on her Masters in Mechanical Engineering. Her research interests include engineering education and design for manufacturing. She earned a BS in Mechanical Engineering at Northeastern University in 2008.

\section{Russell Korte, University of Illinois, Urbana-Champaign}

Russell Korte is an Assistant Professor of Human Resource Education at the University of Illinois at Urbana-Champaign. He is currently a Fellow with the iFoundry project in the College of Engineering at the University of Illinois. His research investigates how engineering students navigate their education and how engineering graduates transition into the workplace. Additional research interests include theory, philosophy, workplace learning and performance, socialization, adult education, social psychology, and organization studies.

\section{Micah Lande, Stanford University}

Micah Lande is a Ph.D. candidate in Mechanical Engineering and Design at the Center for Design Research at Stanford University. He is researching how engineers learn and apply a design process to their work. Micah is a co-Editor-in-Chief of Ambidextrous, Stanford University's Journal in Design. His academic interests include design and engineering education, design thinking and foresight thinking, creativity and innovation, and interdisciplinarity and multidisciplinarity in higher education. He has a B.S in Engineering from Stanford's Product Design program and has a M.A. in Education from the Stanford School of Education program in Learning, Design and Technology.

\section{Sheri Sheppard, Stanford University}

Sheri D. Sheppard is the Burton J. and Deedee McMurtry University Fellow in Undergraduate Education, Associate Vice Provost for Graduate Education, and Professor of Mechanical Engineering at Stanford University. She is also a consulting senior scholar at the Carnegie Foundation, having directed the Preparations for the Professions Program (PPP) engineering study, and co-authored the study's report Educating Engineers: Designing for the Future of the Field (2008). Before coming to Stanford University, she held several positions in the automotive industry, including senior research engineer at Ford Motor Company's Scientific Research Lab. She earned a Ph.D. at the University of Michigan. 


\title{
Supports and Barriers that Recent Engineering Graduates Experience in the Workplace
}

\begin{abstract}
One of the aims of engineering education is to prepare students for engineering in the $21^{\text {st }}$ century. Yet critics of engineering education point to the lack of preparation students obtain in school. This paper examines the career supports and barriers that one cohort of recent engineering graduates experienced in the workplace. Social Cognitive Career Theory (SCCT) describes supports and barriers as environmental factors that individuals perceive as having the potential to either aid or hinder their pursuit of a particular career goal. ${ }^{1}$ In this study, supports and barriers are identified in the engineering departments of four U.S.-based companies. The data were gathered from semi-structured interviews with 59 newly hired engineers who had recently graduated from college. In two of the companies, Big Food Company and Small State Agency, new hires complete a rotation period in which they work in three different departments before being assigned to a permanent position and the work is mostly project management-based. In the other two companies, Big Car Company and Small Computer Company, engineers are assigned to a permanent position and do a mix of technical and project management work. The interviews from these companies were analyzed both quantitatively and qualitatively.
\end{abstract}

The analysis of interviews shows that both supports and barriers in the workplace are created by the company, by managers, and by coworkers. For example, a manager would serve as a support when she supplies needed information to the new engineer and as a barrier when she is too busy to provide feedback in a timely fashion. Many supports and barriers were found to be common across all four companies. In addition, several factors were mentioned by the new engineers as being both supports and barriers, suggesting that local circumstances and individual perspectives play a role in the experiences of new engineers as well. Finally, the data also suggest that supports and barriers may influence new engineers' job satisfaction.

The outcome of this research is a three-pronged taxonomy meant to help companies develop greater empathy for their new hires, to help educators better inform and prepare students for the engineering workplace, and to enable students to more skillfully investigate potential employers and careers. The implications and research findings are discussed for each group.

\section{Introduction}

Much of engineering education research today looks at graduates' preparedness for the workplace as a means to evaluate engineering curricula. Research by Lattuca et al. ${ }^{2}$, Anderson et al. ${ }^{3}$, and Murray ${ }^{4}$ has assessed graduates' preparedness from the viewpoints of seniors, faculty, department chairs, and employers. Yet, with the exceptions of Polach ${ }^{5}$, Korte et al. ${ }^{6}$, Eraut et al. ${ }^{7}$, and Tilli et al. ${ }^{8}$, few studies have sought input from the new engineers themselves. This paper bridges the gap by examining the supports and barriers that one cohort of recent engineering graduates experienced in the workplace, as told in their own words. With this knowledge, engineering programs can be improved to foster support-building and barrier-coping behaviors in 
their students that will serve them in the transition from school to work and throughout the rest of their careers.

Supports and barriers, as called out in Lent's Social Cognitive Career Theory, are environmental factors that individuals perceive as having the potential to either aid or hinder their pursuit of a particular career goal. ${ }^{1}$ Supports and barriers also have the potential to influence domain-specific subjective well-being such as job satisfaction. ${ }^{9}$ Job satisfaction, as classically defined by Locke, refers to a "pleasurable or positive emotional state resulting from the appraisal of one's job or job experiences". 10 The authors assume that this extends beyond extrinsic satisfaction (e.g. with salary) to satisfaction with the work itself, the context, and the people involved. According to SCCT, supports and barriers can influence job satisfaction directly and indirectly through selfefficacy and outcome expectations. In other words, the amount of support that an individual receives can significantly affect their beliefs about their ability to succeed and the outcomes of succeeding, which can in turn affect their job satisfaction. ${ }^{9}$

With regards to engineering, SCCT has only been used to study college students and mid-career professionals. Lent et al. used SCCT to predict academic interests and goals among engineering students in a number of studies. ${ }^{11,12}$ Trenor et al. used SCCT to investigate the role of ethnicity in female engineering students' educational experiences and vocational plans. ${ }^{13}$ The authors of the current study propose that the SCCT model might be extended to explain the propensity for new engineers to be satisfied or dissatisfied with their jobs. New engineers' early work experiences are critical in that, during this time, they form enduring perceptions about their work, their company, and their profession which strongly influence their decisions to stay or quit. ${ }^{14}$ The authors propose then that these experiences moderate new engineers' job satisfaction, which is a precursor to many other occupational outcomes including commitment to a career in engineering. Preliminary evidence of this has been provided by the Society of Women Engineers, which recently reported that negative work climate as a reason for leaving engineering has been on the rise among new graduates since $2000 .{ }^{15}$ Thus the purpose of this paper is 1) to identify the supports and barriers that new engineers commonly face in the workplace, and 2) to understand how these supports and barriers might affect new engineers' job satisfaction.

The current study was informed by two previous qualitative studies on recent engineering graduates. The first study, conducted by Polach in 2004, looked at eight new product engineers at a medical device manufacturer and found that the ability to befriend coworkers and navigate an ambiguous work environment was critical to the new hire's overall work satisfaction. ${ }^{5}$ The second study, conducted by Korte et al. in 2008, looked at 17 new engineers at a large, international car manufacturer which they termed Big Car Company. Like Polach, they showed that new engineers in this organization relied heavily on coworkers for help and that an understanding of the larger organization was crucial to the understanding of their own day-to-day work. ${ }^{6}$ Viewing these findings in terms of supports and barriers, high-quality relationships with coworkers and an understanding of "the big picture" could be considered supports for new engineers while the lack of either could be considered barriers. This paper applies the same support/barrier framework to Korte et al.'s original data set, consisting of interviews with 59 new engineers at four different U.S.-based companies including Big Car Company. In addition to 
identifying other supports and barriers, this paper compares the supports and barriers reported at the four companies to determine key trends among them.

A cross-case comparison of the data showed that many supports and barriers are common to all four companies. Several of these factors were reported as both a support and a barrier. Finally, the data also suggest that supports and barriers may influence new engineers' job satisfaction in accordance with SCCT.

\section{Research Methodology}

The data used in this study were gathered from semi-structured interviews with 59 newly hired engineers at four different U.S.-based companies. The data from the participants were analyzed both qualitatively and quantitatively.

\section{Data Collection}

The participants in this study were 59 newly hired engineers who had been in the workplace from 6 months to 2 years. The participants were recent college graduates starting their first professional job out of school. They included both male and female participants, as well as participants from different ethnic groups.

The 59 new engineers were employed by four different U.S.-based companies. As previously mentioned, Big Car Company is a large international vehicle manufacturer. Small Computer Company is a small computer company which specializes in hardware manufacturing. At both Big Car Company and Small Computer Company, employees are mostly mechanical and electrical engineers. They are assigned to a permanent position upon hire, and do a mix of technical and project management work. Big Food Company is a large, national food manufacturer which employs mostly chemical engineers. Small State Agency is a small, state transportation agency which employs mostly civil engineers. At both Big Food Company and Small State Agency, new hires complete a rotation period in which they work in three different departments before being assigned to a permanent position and the work is mostly project management-based. The numbers of new engineers interviewed at each company are as follows: 17 from Big Car Company, 15 from Small Computer Company, 18 from Big Food Company, and 9 from Small State Agency.

All 59 participants were interviewed once in early 2007. Each interview lasted between 50 and 90 minutes. The interviews were recorded and transcribed, and the transcripts were verified with the original recordings by the interviewer. The interviews were semi-structured, following the Critical Incidents Technique. ${ }^{16}$ The semi-structured format allows for unexpected data to emerge from the interview and allows the interviewer to probe more deeply into particular experiences to investigate details more thoroughly. To collect important experiences or critical incidents, the interviewer asked each participant to recall 1-2 projects or problems assigned to them for which they had to use their technical expertise to solve. The participants were also asked to describe their experiences as new hires, what they had learned about the company and the ways work was done there, and how their company's on-boarding process could have been improved to better 
facilitate their transition into the workplace. Finally, participants were also asked about their 3-5 year career plans.

This study had several limitations. First, the authors gathered their data from a pre-existing set of interviews meant to explore how newly hired engineers begin practicing engineering in the workplace. Since the interviews were not specifically designed to probe workplace supports and barriers, certain questions could not be answered, including the extent to which personal factors affect how new engineers perceive support and barriers. Furthermore, the four companies involved in the study agreed to participate as long as their identities were kept anonymous, even to the authors. Thus, the authors were limited in their ability to take into account company culture, company goals, etc., in their interpretation of the findings. Yet despite these limitations, the data set still provided valuable insight into supports and barriers and their relations to job satisfaction.

\section{Data Analysis}

Analysis of the interview transcripts was done in $\mathrm{Nvivo}^{\mathrm{TM}}$ and followed the qualitative analysis procedures detailed by Taylor and Bogdan ${ }^{17}$ and Strauss and Corbin ${ }^{18}$. In reviewing the transcripts, the authors saw the potential to do some preliminary probing into supports and barriers that recent engineering graduates experience in the workplace. To this end, the transcripts showed that supports and barriers were created by the company, by managers, and by coworkers. Thus, for each transcript, predetermined codes were attached to statements describing supports and barriers. Six different predetermined codes were used, each of which consisted of a type (support or barrier) and a level (company, manager, or coworker). A detailed description of each predetermined code is shown in Table 1. Next, all statements describing supports and barriers were retrieved and open-coded at a finer level of detail. This procedure of assigning predetermined codes and open codes to the data was repeated for all four companies, with each new company building on the open-coding scheme that emerged from the last. In total, 67 opencodes were created. After open-coding was completed, the open codes were grouped into 24 thematic categories, or themes. Each theme represents a different kind of support or barrier (e.g. 'Coworkers provide help with work' or 'Managers help with career development'). 
Table 1. Predetermined Codes Applied to the Interview Transcripts

\begin{tabular}{|c|c|c|}
\hline Codes & Definition & Examples \\
\hline $\begin{array}{c}\text { Company } \\
\text { Support }\end{array}$ & $\begin{array}{c}\text { A positive experience/incident created } \\
\text { partly or wholly by the company (i.e. } \\
\text { "upper management" and other high-level } \\
\text { functions like HR) }\end{array}$ & $\begin{array}{c}\text { Merit-based promotion practices, } \\
\text { diversity in the company, efficient } \\
\text { work procedures, mentoring programs }\end{array}$ \\
\hline $\begin{array}{c}\text { Company } \\
\text { Barrier }\end{array}$ & $\begin{array}{c}\text { A negative experience/incident created } \\
\text { partly or wholly by the company (i.e. } \\
\text { "upper management" and other high-level } \\
\text { functions like HR) }\end{array}$ & $\begin{array}{c}\text { Politics-based promotion practices, lay- } \\
\text { offs, inefficient work procedures, } \\
\text { inadequate orientation to company, } \\
\text { department or job }\end{array}$ \\
\hline $\begin{array}{c}\text { Manager } \\
\text { Support }\end{array}$ & $\begin{array}{c}\text { A positive experience/incident created } \\
\text { partly or wholly by the new hire's direct } \\
\text { supervisor(s) }\end{array}$ & $\begin{array}{c}\text { Manager pleasant to work for, manager } \\
\text { provides career counseling, manager } \\
\text { provides needed information }\end{array}$ \\
\hline $\begin{array}{c}\text { Manager } \\
\text { Barrier }\end{array}$ & $\begin{array}{c}\text { A negative experience/incident created } \\
\text { partly or wholly by the new hire's direct } \\
\text { supervisor(s) }\end{array}$ & $\begin{array}{c}\text { Manager sets a bad example for new } \\
\text { hire, manager does not provide career } \\
\text { counseling, manager too busy to help } \\
\text { with work }\end{array}$ \\
\hline $\begin{array}{c}\text { Coworker } \\
\text { Support }\end{array}$ & $\begin{array}{c}\text { A positive experience/incident created } \\
\text { partly or wholly by the new hire's } \\
\text { coworker(s) }\end{array}$ & $\begin{array}{c}\text { Coworker mentor or coach, teamwork, } \\
\text { camaraderie with coworkers, coworkers } \\
\text { provide help with work }\end{array}$ \\
\hline $\begin{array}{c}\text { Coworker } \\
\text { Barrier }\end{array}$ & $\begin{array}{c}\text { A negative experience/incident created } \\
\text { partly or wholly by the new hire's } \\
\text { coworker(s) }\end{array}$ & $\begin{array}{c}\text { Competition with coworkers, lack of } \\
\text { teamwork, lack of camaraderie, } \\
\text { coworkers too busy to help with work }\end{array}$ \\
\hline
\end{tabular}

Once all coding was finalized, the supports and barriers for each company were evaluated by type, by level, and by theme using the cross-case comparison method. ${ }^{19}$ For the comparison by theme, instances in which only one participant reported experiencing a particular support or barrier in a given company were removed under the assumption that this indicates an outlier rather than a norm.

\section{Data Representation}

The conventions used for quotes in this paper are as follows: All names, belonging to the participant or otherwise, have been redacted and replaced with a generic placeholder, i.e. [name] with brackets and italicized words, to indicate that information was removed. The same was done for any other information which could possibly help to identify the individual, such as the names of companies or schools. Words and phrases that detract from the clarity and meaning of the quotes such as "um", "you know", "like", and "I mean" have also been removed and replaced with ellipses.

\section{Findings}

Analysis of the interview transcripts showed that new engineers at all four companies face a variety of supports and barriers in the workplace. In doing this study, the authors were interested to know not only what these supports and barriers are but also how they compare across different kinds of companies. 


\section{Comparison by Type and Level}

Table 2 presents the cross-case comparison of supports and barriers by type and level. The numbers under each company heading correspond to the number of participants from that company who reported the support or barrier.

Table 2. Number of Participants Reporting Supports and Barriers by Type and Level

\begin{tabular}{|l|cc|cc|cc|cc|}
\cline { 2 - 9 } \multicolumn{1}{c|}{} & \multicolumn{2}{c|}{\begin{tabular}{c} 
BCC \\
\multicolumn{1}{c|}{}
\end{tabular}} & \multicolumn{2}{c|}{\begin{tabular}{c} 
BFC \\
\multicolumn{1}{c|}{}
\end{tabular}} & \multicolumn{2}{c|}{$\begin{array}{c}\text { SSA } \\
\mathrm{n}=17\end{array}$} & \multicolumn{2}{c|}{$\begin{array}{c}\text { SCC } \\
\mathrm{n}=15\end{array}$} \\
\hline Supports & 17 & $100 \%$ & 17 & $94 \%$ & 9 & $100 \%$ & 15 & $100 \%$ \\
Supports - Company & 11 & $65 \%$ & 12 & $67 \%$ & 9 & $100 \%$ & 13 & $87 \%$ \\
Supports - Managers & 15 & $88 \%$ & 15 & $83 \%$ & 8 & $89 \%$ & 14 & $93 \%$ \\
Supports - Coworkers & 17 & $100 \%$ & 17 & $94 \%$ & 9 & $100 \%$ & 15 & $100 \%$ \\
\hline Barriers & 17 & $100 \%$ & 17 & $94 \%$ & 9 & $100 \%$ & 14 & $100 \%$ \\
Barriers - Company & 17 & $100 \%$ & 16 & $89 \%$ & 8 & $89 \%$ & 13 & $87 \%$ \\
Barriers - Managers & 9 & $53 \%$ & 7 & $39 \%$ & 2 & $22 \%$ & 11 & $73 \%$ \\
Barriers - Coworkers & 13 & $76 \%$ & 13 & $72 \%$ & 6 & $67 \%$ & 13 & $76 \%$ \\
\hline
\end{tabular}

Table 2 shows that nearly every new engineer interviewed for this study reported experiencing at least one support and one barrier since they had started working. This finding is evidence that, whether or not they sought it, each one of them had received some kind of support from their company or work group (i.e., manager and coworkers). At the same time, almost no one had had a "flawless" on-boarding experience, which meant that they had to learn how to cope with barriers at least to some extent.

Looking at supports by level revealed other trends as well. With the exception of Small State Agency, participants at each work site reported more coworker and manager supports than they did company supports. This finding corroborates earlier evidence that the work group plays a crucial role in helping new engineers assimilate into the company. ${ }^{6}$ However, another reason for this trend could be that coworker and manager supports are simply more visible to new engineers than company supports. Except in extreme cases, most new engineers reported that they interact with their coworkers and managers on a daily or weekly basis. Conversely, most company supports happen infrequently (e.g. orientation, training), while still others, like those related to long-term career development, may not be perceptible to the new engineer until they have been at the company for some time.

With respect to barriers, reports of company-level barriers outnumbered reports of manager and coworker barriers at every site. By and large, the new engineers interviewed for this study found the procedures, politics, and "paperwork" of their company to hinder what they perceived as efficient and effective work practices. Several of them struggled to cope with the numerous rules and regulations that hampered their work. This, coupled with the lack of a tangible connection to the company described in the previous paragraph, could explain why the new engineers complained about the company more often than they did about their coworkers or managers. 


\section{Comparison by Theme}

The supports and barriers reported at each company were also analyzed by theme. The themes that emerged from the data are shown grouped by type and level in Table 3 . The numbers on the right of each column refer to the number of companies in which a given theme was reported.

Table 3. Categorization of Supports and Barriers by Theme

\begin{tabular}{|c|c|c|c|c|}
\hline & \multicolumn{2}{|l|}{ Supports } & \multicolumn{2}{|l|}{ Barriers } \\
\hline \multirow{5}{*}{ 芯 } & Employee education & 4 & Problems with employee education & \\
\hline & Company facilitates progress & 3 & Company impedes progress & \\
\hline & New hire socialization & 3 & Problems with new hire socialization & \\
\hline & Positive work environment & 2 & Frustrating work environment & \\
\hline & Company helps with career & 11 & Problems with on-boarding & \\
\hline \multirow{4}{*}{$\begin{array}{l}\bar{d} \\
\mathbb{8} \\
\widetilde{\Xi} \\
\bar{\Sigma}\end{array}$} & Manager helps with work & 4 & Manager does not help with work & \\
\hline & Manager a positive role model & 3 & Manager not a good role model & \\
\hline & Manager inclusive of new engineer & 4 & & \\
\hline & Manager helps with career & 4 & & \\
\hline \multirow{5}{*}{ 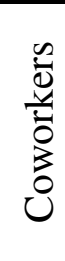 } & Co-workers help with work & 4 & Coworkers do not help with work & \\
\hline & Camaraderie with coworkers & 4 & Lack of camaraderie with coworkers & \\
\hline & Teamwork with coworkers & 2 & Lack of teamwork with coworkers & \\
\hline & Coworker mentor or coach & 2 & & \\
\hline & Coworkers help with career & 1 & & \\
\hline
\end{tabular}

A cross-case comparison of the data showed that many supports and barriers are common to all four companies; that is, at least two participants from every company reported experiencing them in their interviews. These supports and barriers stem from all three levels, i.e. from the company, from managers, and from coworkers. Common supports and barriers are shown with their definitions in Table 4 and Table 5, respectively. 
Table 4. Definitions of Supports Common to all Companies

\begin{tabular}{|c|c|}
\hline Theme & Definition \\
\hline Employee education & $\begin{array}{l}\text { Company provides opportunities for employee learning and growth, } \\
\text { such as orientation, training, and rotation programs. }\end{array}$ \\
\hline $\begin{array}{l}\text { Manager helps new } \\
\text { engineer with work }\end{array}$ & $\begin{array}{l}\text { Manager helps new hire with day-to-day work, providing information } \\
\text { and feedback, answering questions, and intervening on the new hire's } \\
\text { behalf when needed. }\end{array}$ \\
\hline $\begin{array}{l}\text { Manager is inclusive } \\
\text { of new engineer }\end{array}$ & $\begin{array}{l}\text { Manager is inclusive of new hire by keeping him (or her) in the loop, } \\
\text { listening to his ideas, and giving him autonomy over his own work. }\end{array}$ \\
\hline $\begin{array}{c}\text { Manager helps new } \\
\text { engineer with career } \\
\text { development }\end{array}$ & $\begin{array}{l}\text { Manager helps with new hire's long-term career development by } \\
\text { having one-on-one meetings with him (or her), giving him career } \\
\text { advice, and guiding him toward opportunities which will help him in } \\
\text { the long run. }\end{array}$ \\
\hline $\begin{array}{l}\text { Coworkers help new } \\
\text { engineer with work }\end{array}$ & $\begin{array}{l}\text { Coworkers help new hire with day-to-day work by providing } \\
\text { information and contacts and by answering questions. This is a one- } \\
\text { way interaction in which the new hire depends on his or her coworkers. }\end{array}$ \\
\hline $\begin{array}{l}\text { Camaraderie with } \\
\text { coworkers }\end{array}$ & $\begin{array}{l}\text { New hire develops high-quality relationships with his or her coworkers, } \\
\text { especially when they share an interest and are close together in age. } \\
\text { They might spend time together in and/or outside of work. }\end{array}$ \\
\hline
\end{tabular}

Table 5. Definitions of Barriers Common to all Companies

\begin{tabular}{|c|c|}
\hline Theme & Definition \\
\hline $\begin{array}{c}\text { Problems with } \\
\text { employee education }\end{array}$ & $\begin{array}{c}\text { Company has serious flaws in their practices for employee } \\
\text { learning and growth, such as inadequate orientation or training. }\end{array}$ \\
\hline $\begin{array}{c}\text { Frustrating work } \\
\text { environment }\end{array}$ & $\begin{array}{c}\text { Company creates an environment for new hire which leads to low } \\
\text { work satisfaction: excessive bureaucracy, not open to new ideas, } \\
\text { overwhelming or underwhelming workloads, etc. }\end{array}$ \\
\hline $\begin{array}{c}\text { Manager does not } \\
\text { help new engineer } \\
\text { with work }\end{array}$ & $\begin{array}{c}\text { Manager does not help new hire with day-to-day work. In some } \\
\text { cases, the manager is either too busy to help, or is inexperienced } \\
\text { and therefore is no real help. In other cases, the manager simply } \\
\text { does not care enough to help. }\end{array}$ \\
\hline $\begin{array}{c}\text { Coworkers do not } \\
\text { help new engineer } \\
\text { with work }\end{array}$ & $\begin{array}{c}\text { Coworkers do not help new hire with day-to-day work. In some } \\
\text { cases, the coworkers are either too busy to help, or are } \\
\text { inexperienced and therefore are no real help. In other cases, the } \\
\text { coworkers simply do not care enough to help. }\end{array}$ \\
\hline $\begin{array}{c}\text { Lack of camaraderie } \\
\text { with coworkers }\end{array}$ & $\begin{array}{c}\text { New hire fails to develop high-quality relationships with his or } \\
\text { her coworkers, especially when they do not share any interests } \\
\text { and are far apart in age. }\end{array}$ \\
\hline $\begin{array}{c}\text { Lack of teamwork } \\
\text { with coworkers }\end{array}$ & $\begin{array}{c}\text { Coworkers will not willingly work with the new hire in mutual } \\
\text { collaboration, will not listen to his or her ideas, etc. Coworkers } \\
\text { also compete and struggle with the new hire. }\end{array}$ \\
\hline
\end{tabular}

Table 4 and Table 5 show that some themes appear under both supports and barriers. For instance, new engineers at every company named opportunities for employee education as a support, but they reported significant problems with these programs as well. They also said that while coworkers and managers help them with work, (i.e., help them learn what to do and how to 
do it), these individuals do not help them enough. Finally, new engineers reported both having 'camaraderie' and not having camaraderie with their coworkers.

In summary, the data showed that many supports and barriers were common to all four companies and that certain factors were perceived by the new engineers as being both supports and barriers. The next section uses qualitative data from the participant interviews to explore these findings in more detail. It also highlights several instances in which workplace supports and barriers may be linked to new engineers' job satisfaction.

\section{Discussion}

\section{Themes Under Both Types}

As mentioned, there were several factors that new engineers at all four companies perceived as being both supports and barriers. These factors are employee education, help with work from managers and coworkers, and camaraderie with coworkers. Each factor will be explored in more detail to better understand the nuances involved.

\section{A. Employee Education}

Employee education refers to opportunities provided to new engineers that promote learning and growth, such as orientation, training, and rotation programs, if the company had one. New engineers at every company reported ample access to technical training through on-site classes, on-line classes, books, videos, and apprenticeships. Plus, Big Food Company and Small State Agency offered training on non-traditional subjects such as business, teamwork, and communication.

Yet new engineers at every company also reported that the company's efforts at employee education were not enough. These individuals felt that they were not given enough information about the way things worked in the company up front. This was true even for Big Food Company and Small Car Company, both of which provide a formal day-long orientation to the company and to the engineering department within the new hire's first month of work. A frequent complaint was not getting an explanation of 'the big picture" ${ }^{\prime 6}$ and where they fit within the company. At the time of their interview, several participants had developed a general understanding of their role and position in the company with help from their managers and coworkers. Other participants, however, were still looking for guidance on this topic.

I wanted always more overview, more overview. Tell me about how the whole company process and procedures work. How does this person fit in with that person? I was getting into too much depth of information on specifics without getting an overview... So I was constantly asking people, especially my first two, three weeks, give me an overview. Back up, you're getting too specific. Let me see this overview. I was asking my managers that. (Small Computer Company, 07-014)

Related to employee education, a clean division in new engineers' opinions was seen at the two companies with rotation programs, Big Food Company and Small State Agency. Some new 
engineers reported liking the rotation program because it provided them with a breadth of experience and helped them determine where they best fit in the company.

So far, I enjoy it a lot, this program. It's a very, very, very good program. Because first of all, it will give me opportunity to go around and see what's going on within [department], and be able to see, be able to choose what I want to be. (Small State Agency, 05-019)

Another group of new engineers were not as enthusiastic about the rotation program. They complained that it was difficult to make significant contributions in a three to six-month window. They also expressed concern over not knowing what their permanent position would be.

I think the other thing is right now we don't know where we're [going to] be permanently hired. We [have to] do our two-year rotation. In a sense, it's good, because you kind of have a feeling for each position, and then you might know where you want to go at the end of the year. But on the other hand, you have no idea where you're [going to] end up, so it's hard to concentrate on something within the two years. You can't plan ahead of time, I'm [going to] be doing construction so I [have to] concentrate on my construction rotation. (Small State Agency, 05-017)

In the cases above, two new engineers from the same company expressed very different feelings about the rotation program. This is evidence that individual perspective may affect whether a new engineer perceives a work experience as a support or a barrier as well.

\section{B. Help with Work}

\section{B1. Help from Managers}

At all four companies, several participants reported that their managers helped them with their day-to-day work. In other words, their managers answered their questions, provided them with timely feedback, put them in touch with needed resources, and acted on their behalf when necessary.

Well, [company]'s a big organization and I think I was very fortunate because when I started the position, my initial supervisor was very - they were very good at throwing things at you that you might not even know why you need them. And so in training they throw in their past experience, how they filled something out, how they submitted something, what training classes they would go to. So I was very fortunate to have a supervisor... that without me asking a lot of questions, would provide things for me. (Small State Agency, 05-004)

Other participants reported having managers that did not provide enough help for various reasons. Some managers were too busy to help because they had to balance both supervisory and project responsibilities. As a result, these managers had very little interaction with their employees; in some cases, they were not even there to greet new engineers on their first day of work. 
My manager wasn't there to greet me or nobody was there to be like - hey welcome aboard, blah, blah, blah. There was... one random dude... They were like - do you know where [manager] is? No, I don't know where he is. And now I know why they don't know where he is, because he's busy as hell and he's never at his desk. They're like - do you know where he is? No, no, no. So then I just kind of like sat and then it was like almost lunchtime, they're like - you want to go to lunch? So I went to lunch with two people that, one of which is not even there anymore, the other person I hardly ever talk to because I don't really work with him. And it was so weird. And then I went like the first week or something, never even met my manager. (Big Car Company, 06-012)

Some participants reported having a manager that was new like them, either because they had just joined the company or because they transferred in from another department. In cases like these, the manager was also learning the ropes and could only offer limited support; therefore, the new engineer had to seek out additional sources of help.

He [manager] actually started the same day I did, and so he had been with the company but not at the plant and so it was a little bit rough at first just because he was still trying to figure things out and how he wanted to run the technical department. And I think I was expecting a lot of direction when I first started and so I think I was floundering for a while because he was still figuring out what he was doing and I was like, I need you to tell me what I'm supposed to be doing. And he's like, I haven't quite figure out how I want to do that yet. And so I think that was a little bit rough for me to start. And then I think I just kind of got used to his style. (Big Food Company, 04-006)

\section{B2. Help from Coworkers}

As with managers, new engineers at every company reported varying degrees of help from the coworkers. Many participants said that their coworkers helped them understand what is expected of them and helped them accomplish their work. Other participants said that their coworkers were too busy or too new to the work group to provide much help.

Q: Did your [coworker] give you this assignment?

A: Yes.

Q: I assume he gave you background information?

A: Yes and no. We both were new to this [name] system, so we pretty much were on the same page in terms of understanding the system. So it was like we both learned it at the same time. I found some information, I talked to him about it, he found some more information about it. That way we together executed the project. (Big Food Company, 04-018)

Some new engineers discovered that they received varying levels of help depending on which coworkers they approached, as shown in the following passage: 
Q: Was it easier to relate to some people than others?

A: Yeah, I think some people are a little more approachable than others.

Q: And what's the difference?

A: I guess maybe it's their personality or maybe their just willingness to help you out and stick around till it's done. And with some engineers you get this feeling like they're too busy to help you. You'll get five minutes of their time and then their phone rings and they've got to go. And then there's others that are just easily more approachable and you can call them up and they'll come out and they'll help you out. (Big Car Company, 06-010)

\section{Camaraderie with Coworkers}

At every company, participants reported a wide spectrum of relationships with their coworkers. On one end of the spectrum, participants reported having strong camaraderie with their coworkers, i.e., they felt like "a part of the group" (Big Car Company, 06-011). In many of these cases, the participants found it easy to develop camaraderie because the people in their work group were friendly, respectful of one another, and open to communication. It also helped if the new engineer had something in common with their coworkers, for example, if they were close in age or shared similar interests.

Q: Yeah. Well, let's talk a little bit about your group that you work with, some of the other people. You said there are about 20 people in there?

A: Um hmm.

Q: When you first came into the group, what did you think and feel about meeting these people and how it was going to be?

A: It was... much easier because I think we were all in the same age group, so integrating with the group was really easy. I think we got to know them, they got to know you. And it's like I was here for maybe ten years, I mean it just - you just have that type of feeling to it, you know? (Big Car Company, 06-020)

For many new engineers, the degree of camaraderie that they shared with their coworkers played an important role in their socialization to the company. In the best examples, they would go out to lunch with their coworkers, and they also regularly engaged in talk about non-work-related topics like family and sports. Some new engineers socialized with their coworkers outside of work as well. During the week, they played sports and went out to dinner. On the weekends, they went to the movies, watched TV, and even raced cars.

Myself personally, I've associated a lot with a lot of... people in our group. Another person in our group races his car, so we go to races together, which is a big time commitment, so we spend a lot of time together and we've become good friends I would say. The other person who hired in is also a young guy who went to [school], so we get together and watch [school] games together and such. So definitely very comfortable with the people and it is a very friendly atmosphere. (Big Car Company, 06-017) 
On the other end of the spectrum were new engineers who felt little to no camaraderie with their coworkers. This was usually due to a significant difference in age or a mismatch of outside interests.

The only thing negative is that within our plant there's a lot of people my age or a few years older, but a lot of what people seem to do is to go out for drinks or whatever and I think the only negative thing is that I'd rather do something else... through volunteering together or something different as opposed to always going out for drinks or to watch football games or stuff like that. (Big Food Company, 04-002)

Several new engineers fell somewhere in the middle of the spectrum. Some claimed to feel alienated by the majority of their work group but were still able to identify one or two coworkers as a friend. Others reported the opposite experience of getting along with all but one or two coworkers.

Q: What differences have you noticed in your coworkers?

A: I guess the most obvious difference is the group I'm working with here is a bit older than where I was at $[$ city]... There was a lot of young people at $[$ city].... So there was more of a sense of community and a sense of togetherness in the sense that we're all kind of starting off on this together and we're all kind of in the same boat. So it was like there were other people you could relate to in that sense. There's a couple folks here, where I'm at right now, there's two girls I work with who both just graduated in the last year, but other than that, I'm probably the third youngest person in this plant right now. So just in having that camaraderie is a little bit different. There's fewer people to bounce ideas off of. (Big Food Company, 04-009)

Q: Have you experienced any situations where maybe people were reluctant to share information with you?

A: Not a lot. But a particular colleague... It's like she can get all the information she wants, but... she doesn't want to spend any time on what is not on her project or lots of things. So I did experience that. And once you experience that, you get to know or you tend to keep away from asking them questions a lot. But that's... one person in our group. (Big Car Company, 06-028)

The data also exposed a problem unique only to Big Food Company and Small State Agency, the two companies with rotation programs. Coworkers there seemed reluctant to build camaraderie with new engineers, simply because for them, it was not a worthwhile proposition. Rotations in these companies only last three to six months, and so by the time the coworkers got to know the new engineer, the new engineer had left to work in another department.

You're only going to be there for four months. So you could understand where people are like, well, I'm not going to take the time to really get to know you 'cause you're going to be gone in three months. And so you don't really take it personally, but you do kind of. You're like, oh, it would be nice to always be in there. But you can't have it perfect all the time. (Small State Agency, 05-007) 
These feelings seemed especially strong for line operators at Big Food Company. As mentioned, new engineers at Big Food Company typically do project management-based work, which includes overseeing the line operators on the manufacturing floor. It appears that many line operators show resentment over having to take orders from a recent college graduate with almost no real world experience. Furthermore, the line operators may also be skeptical about promises that new engineers have made to them in the past and then not delivered because they moved to another group.

Operators. When you come in there - and this is just maybe my perception - they're a little bit jaded... especially in [plant]. They get a new person that rotates through every six months. So they're a little disgruntled because the way that they see it, you just get the person up to speed and they're gone. And then I think they may have also had to deal with people that were maybe a little on the cocky side, so coming in, they might expect you to be that way. And it takes a little while for them to realize that you're not like that. (Big Food Company, 04-008)

The preceding analysis indicates that many of the supports and barriers that new engineers face in the workplace are common across workplace settings. Yet, even within these supports and barriers, there are differences based on company culture, local circumstances, and individual perspective. A deeper understanding of how these factors influence new engineers' perceptions of supports and barriers could help companies create a more equitable experience for all.

\section{Effects of Supports and Barriers on Job Satisfaction}

As mentioned, the new engineers' long-term career goals were also reported and analyzed. Across all the new engineers studied, the data did not show linkages between workplace supports and barriers and these goals. However, the authors were not surprised by this since the new engineers had only been working from six months to two years and it seemed unlikely that supports and barriers would significantly influence their career goals in that time frame.

However, in some instances, the authors were able to infer new engineers' job satisfaction from the supports and barriers that they experienced. In general, new engineers who received ample supports and encountered few barriers reported positive feelings about their jobs and the work they performed. One new engineer at Small Computer Company cited a number of reasons for his enjoying his job. One reason was the company's positive work environment. According to this new engineer, the company had a very relaxed atmosphere and it was very easy to make acquaintances within the company due to the large number of young people there. Also contributing to the positive work environment was the variety of hands-on work that his job allowed him to do. 
Q: Was there something that kind of stuck in your mind, impressed you the most?

A: I guess what impressed me the most is the variety that I knew I was going to be able to get in a typical day.

Q: Variety of work?

A: The variety of work. Not sitting at my desk all day. Yet some days... there might be days where you have almost the whole day at your desk. And then the next day could be completely different. You might be out on the shop floor the whole time. Other days you might be talking and working with design and the tool room. And all the people interaction kind of was a draw to me. And not just sitting at my desk in front of a computer all day. (Small Computer Company, 07-009)

Conversely, new engineers who experienced many barriers and few supports reported negative feelings about their job and the work they performed. In some cases, the new engineer found that their experiences as a practicing professional simply did not live up to the expectations they had developed as undergraduates. For one new engineer at Big Car Company, this was especially true when he realized that teamwork was not as highly valued in the workplace as he had believed it would be.

Maybe it's this feeling of in school they teach you all about this teamwork effort. In business it's all about teamwork and working together. But then you come out here and I don't feel like I'm part of a team, I don't feel like there's any kind of teamwork thing. Everybody's got their projects and that's all they're focused on is they need to take care of this project and they need to do this and - don't bother me. I work in a group, and essentially that is sort of a team, but... I don't really feel... a team atmosphere like we're all working towards something together... So I guess, and maybe in that regard, I was kind of disappointed. (Big Car Company, 06-010)

This new engineer also expressed disappointment over the lack of camaraderie with his coworkers.

Q: Ok. Is there any kind of socializing that's not about work?

A: Well, there's a couple of people I can socialize with but not too many. Most of these guys are very work-oriented. And I don't know if it's the group I'm in, because a lot of the guys I work with are older. Like there's another girl that started at the same time that I did and she's a new grad... [She] and I [were both] looking forward to the social part of work, you know? Having work and then maybe after work we could go and hang out with these guys and go get a beer or something like that. But in my group, it's not like that. Most of the guys I work with are family guys, they come to work, some of them get there at like 7:00 in the morning and they stay till 5:00 or 6:00, and then they go home and they have families and stuff like that. And at work it's about work and at home it's about home and that's kind of it. So I guess in my group there's not too many people I can relate with. (Big Car Company, 06-010)

In the two cases above, supports and barriers appear to impact how the new engineers' felt about their jobs. In the first case, a relaxed work atmosphere, camaraderie with coworkers, and the ability to do a variety of work created a positive work environment for the new engineer who 
expressed that his work was "kind of was a draw to me." The authors assume that these circumstances gave the new engineer high work satisfaction. In the second case, a single barrier - the lack of camaraderie with one's coworkers - created a "disappointing" work experience for the new engineer. It is possible that disappointment like this contributed to low job satisfaction.

These two cases suggest that workplace supports and barriers may influence new engineers' job satisfaction and that SCCT may be helpful in explaining this phenomenon. Understanding how supports and barriers affect job satisfaction might help employers create more positive work experiences for their new engineers. This understanding might also help engineering programs better prepare their graduates for the workplace. For example, engineering programs might instill in students a more robust self-efficacy as well as more realistic outcome expectations about engineering work.

\section{Implications}

Based on the findings, there are important implications for engineering practice and engineering education. First, organizations might better guarantee new engineers' job satisfaction if they offered more supports and helped eliminate barriers. The data suggest, for example, that new engineers would benefit from a more comprehensive orientation to the company, to the engineering department, and to the work group upon first starting work. The data also suggest that new engineers would appreciate opportunities for social networking as well as formal mentoring by a senior member of their own work group, such as an experienced coworker. By implementing redundant supports like mentors, organizations would make sure that the new engineers almost always have someone to turn to for help, even if their immediate supervisor or coworkers were momentarily unavailable.

Engineering programs might also help better inform and prepare students for engineering work by introducing them to some of the supports and barriers that they may encounter. The goal would be to foster support-building and barrier-coping behaviors that students can take with them into the workplace. One way that engineering educators can achieve this is through "cognitive apprenticeship" 20 in which students are exposed to professional practice through a series of carefully staged and monitored steps. First, educators provide students with explicit models of practice. Then they scaffold students' efforts to imitate practice, and provide feedback on student performance where needed. Over time, the scaffold is withdrawn and students are given greater autonomy as their performance increases. ${ }^{21}$ Ideally, this process is repeated several times, starting from more distant and moving toward closer "approximations of practice". ${ }^{22}$. Rather than immerse students in the full complexity of practice at the outset, the level of challenge and amount of feedback that students receive are appropriated based on where they are in their program. For example, students may start with simple engineering design tasks in their freshman year and build toward exercises more representative of actual practice by senior year. In this way, engineering educators can help students gain a better understanding of what engineering looks like without necessarily overburdening them. ${ }^{21}$

With regards to specific pedagogies, engineering educators may want to consider implementing problem-based or project-based learning in their classrooms. ${ }^{23,24}$ Whether done individually or in a team, both pedagogies can provide good approximations to engineering practice. Not only do 
they expose students to real engineering problems, they also require students to develop a network of resources from which to get information and assistance. In short, they require students to marshal supports and overcome barriers.

Critics of problem-based and project-based learning point to the difficulty of designing, implementing, and managing such programs. ${ }^{23}$ They also express the concern that emphasis on the ill-structured nature of engineering work may frustrate students. However, it has been reported by many educators and students alike that maintaining the status quo in engineering education is problematic for both student satisfaction and teacher evaluations. Furthermore, problem-based and project-based learning have known benefits including more positive student attitudes, deeper conceptual understanding, and better retention of knowledge than traditional instruction. ${ }^{25,26}$ The authors propose that these pedagogies might help increase student selfefficacy and outcome expectations as well. Educators who still anticipate high levels of student frustration are encouraged to try the "approximations of practice" 22 model described above. In this way, they can select problems or projects that best reflect their students' capabilities, starting simply and increasing the ambiguity and uncertainty involved over time.

Finally, the current research might enable soon-to-be engineering graduates to more skillfully investigate potential employers. As the data show, the new engineer experience is shaped not only by the company one chooses to work at but by the work group and the manager to which one is assigned. Thus, students would do better to ask more questions about corporate culture and work group dynamics during their job interviews to ensure that the company they choose is a good fit.

\section{Conclusions and Future Work}

Using semi-structured interviews with 59 new engineers at four U.S.-based companies, this study sought a better understanding of the supports and barriers that recent engineering graduates face in the workplace. The data show that supports and barriers are created by the company, by managers, and by coworkers. While many supports and barriers are common across-companies, not all are universal. Company culture, local circumstances and individual characteristics play a role in the experience of the new engineer as well.

The data showed that in some cases, supports and barriers influenced new engineers' feelings about their jobs. These cases are significant because they suggest that workplace supports and barriers may influence new engineers' job satisfaction and that SCCT may be helpful in explaining this phenomenon.

The supports and barriers the new engineers described suggest that organizations could better manage the on-boarding process to help new engineers transition from school to work more successfully. Equally important, engineering programs could provide students with better approximations of engineering practice. Done correctly, pedagogies such as problem-based learning and project-based learning can help students learn how to marshal supports and cope with barriers before they enter the workplace. This would help instill in graduates a more robust self-efficacy and more realistic outcome expectations about engineering work, both of which 
may affect job satisfaction. Finally, engineering students could also use the current research to more skillfully investigate potential employers.

Interviews intended mainly for understanding how new engineers learn on the job have been used to explore workplace supports and barriers and their relations to new engineers' job satisfaction. Because the authors used a pre-existing set, they were limited in their ability to look at supports and barriers in the context of person or company factors. A study that investigates the effects of these factors more deeply could be pursued in the future.

This work presents other opportunities for future research as well. First, extending this study to other companies could help determine to what extent the findings thus far apply to new engineers in general. A longitudinal study following engineering graduates from school to several years in the workplace could also allow for better understanding of the effects of workplace supports and barriers on job satisfaction and the mechanisms through which these effects occur.

\section{Acknowledgments}

Support for this research came from the National Science Foundation under Grant No. ESI0227558, which funded the Center for the Advancement for Engineering Education (CAEE). The authors would also like to acknowledge the assistance of Helen Chen, George Toye, John Brunhaver, and the new engineers who participated in this study.

\section{Bibliography}

1. Lent, R., Brown, S., Brenner, B., Chopra, S., Davis, T., Talleyrand, R., \& Suthakaran, V. (2001). The role of contextual supports and barriers in the choice of math/science educational options: A test of social cognitive career hypotheses. Journal of Counseling Psychology, 48, 474-483.

2. Lattuca, L., Strauss, L., \& Volkwein, J. (2006). Engineering change: A study of the impact of the EC2000. Baltimore, MD: ABET Inc.

3. Anderson, K., Courter, S., McGlamery, T., Nathans-Kelly, T., Nicometo, C. (2009). Understanding the current work and values of professional engineers: Implications for engineering education. In Proceedings of the American Society for Engineering Education Annual Conference, Austin, TX.

4. Murray, L. (2009). Preparing students for a successful transition from academia: An industry perspective. In Proceedings of the American Society for Engineering Education Annual Conference, Austin, TX.

5. Polach, J. (2001). Understanding the experience of college graduates during the first year of employment in a large corporate environment. Human Resource Development Quarterly, 15(1), 5-23.

6. Korte, R., Sheppard, S., \& Jordan, W. (2008). A Qualitative Study of the Early Work Experiences of Recent Graduates in Engineering. In Proceedings of the American Society for Engineering Education Annual Conference, Pittsburg, PA.

7. Eraut, M. (2007). Learning from other people in the workplace. Oxford Review of Education, 33(4): 403-422.

8. Tilli, S. \& Trevelyan, J. (2008). Longitudinal Study of Australian Engineering Graduates: Preliminary Results. In Proceedings of the American Society for Engineering Education Annual Conference, Pittsburg, PA.

9. Lent, R. \& Brown, S. (2008). Social cognitive career theory and subjective well-being in the context of work. Journal of Career Assessment, 16(1): 6-21.

10. Locke, E. (1976). The nature and causes of job satisfaction. In M. Dunnette (Ed.), Handbook of industrial and organizational psychology. Chicago: Rand-McNally.

11. Lent, R. Brown, S., Schmidt, J., Brenner, B., Lyons, H., \& Treistman, D. (2003). Relation of contextual supports and barriers to choice behavior in engineering majors: Test of alternative social cognitive models. Journal of Counseling Psychology, 50, 458-465. 
12. Lent, R. Brown, S., Sheu, H., Schmidt, J., Brenner, B., Gloster, C., Wilkins, G., Schmidt, L., Lyons, H., \& Treistman, D. (2005). Social cognitive predictors of academic interests and goals in engineering utility for women and students at historically Black universities. Journal of Counseling Psychology, 52(1): 84-92.

13. Trenor, J., Yu, S., Waight, C., Zerda, K., \& Sha, T. (2008). The relations of ethnicity to female engineering students' educational experiences and college and career plans in an ethnically diverse learning environment. Journal of Engineering Education, 97(4), 449-465.

14. Wanous, J. (1992). Organizational entry: Recruitment, selection, orientation and socialization of newcomers, 2nd ed. Reading, MA: Addison-Wesley Publishing.

15. Frehill, L. (2008). The Society of Women Engineers National Survey: Why do women leave the engineering workplace? SWE Magazine, 54(1): 24-26.

16. Flanagan, J. (1954). The critical incident technique. Psychological Bulletin, 51(4), 327-358.

17. Taylor, S., \& Bogdan, R. (1998). Introduction to qualitative research methods, 3rd ed. New York, NY: John Wiley \& Sons.

18. Strauss, A., \& Corbin, J. (1998). Basics of qualitative research: Techniques and procedures for developing grounded theory, 2nd ed. Thousand Oaks, CA: Sage.

19. Eisenhardt, K. (1989). Building theories from case study research. Academy of Management Review, 14(4): 532-550.

20. Collins, A., Brown, J., \& Newman, S. (1989). Cognitive apprenticeship: Teaching the crafts of reading, writing, and mathematics. In L. Resnick (ed.), Knowing, learning, and instruction: Essays in honor of Robert Glaser. Hillsdale, NJ: Erbaum.

21. Sheppard, S., Macatangay, K., Colby, A., \& Sullivan, W. (2009). Educating engineers: Designing for the future of the field. San Francisco, CA: Jossey-Bass.

22. Grossman, P., Compton, C., Igra, D., Ronfeldt, M., Shahan, E., \& Williamson, P. (2009). Teaching practice: A cross-professional perspective. Teachers College Record, 111(9).

23. Smith, K., Sheppard, S., Johnson, D., \& Johnson, R. (2005). Pedagogies of engagement: Classroom-based practices. Journal of Engineering Education, 94(1): 87-101.

24. Dym, C., Agogino, A., Eris. O., Frey, D., \& Leifer, L. (2005). Engineering design thinking, teaching, and learning. Journal of Engineering Education, 94(1): 103-121.

25. Prince, M. (2004). Does active learning work? Journal of Engineering Education, 93(3): 223-231.

26. Felder, R., \& Brent, R. (2005). Understanding student differences. Journal of Engineering Education, 94(1): 5772. 